\title{
An interdisciplinary investigation into the narratives of three co-researchers: A postfoundational notion of practical theology
}

\author{
Author: \\ Juanita Meyer ${ }^{1}$ \\ Affiliation: \\ ${ }^{1}$ Research Institute for \\ Theology and Religion, \\ University of South Africa, \\ South Africa \\ Correspondence to: \\ Juanita Meyer \\ Email: \\ meyerj@unisa.ac.za \\ Postal address: \\ 33 Isabel Street, The Reeds, \\ Centurion 0157, South Africa

\section{Dates:} \\ Received: 21 Aug. 2015 \\ Accepted: 23 Aug. 2015 \\ Published: 16 Nov. 2015 \\ How to cite this article: \\ Meyer, J., 2015, 'An \\ interdisciplinary investigation \\ into the narratives of \\ three co-researchers: A \\ postfoundational notion \\ of practical theology', \\ HTS Teologiese Studies/ \\ Theological Studies 71(3), \\ Art. \#3159, 10 pages. http:// \\ dx.doi.org/10.4102/hts. \\ v71i3.3159

\section{Copyright:} \\ (C) 2015. The Authors. \\ Licensee: AOSIS \\ OpenJournals. This work is \\ licensed under the Creative \\ Commons Attribution \\ License.
}

\section{Read online:}

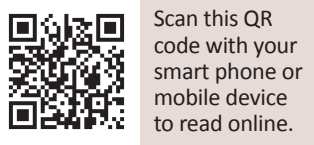

This article elaborates on the sixth movement of a postfoundational notion of practical theology and is concerned with giving a description of experiences, which are thickened through interdisciplinary investigation. The experiences of interest are those of the co-researchers who formed part of the larger research study, conducted in 2010, and who were at the time adolescent male orphans, affected by HIV and AIDS, poverty and father abandonment. The research was conducted within the theoretical frameworks of a postfoundational notion of practical theology, narrative therapy and research, and social constructionism. A qualitative research strategy was employed, with the case study design as point of departure in collecting and analysing research data. Various key aspects were investigated with the use of the model of narrative and the seven movements of a postfoundational notion of practical theology. The aim of this article is to provide an illustration of the application of the principles of a postfoundational notion of practical theology, and its sixth movement - an interdisciplinary investigation - as it is applied within this specific research context. Four interdisciplinary conversationalists, each from a different academic field, were invited to reflect on the three narrated stories of the co-researchers. This article, then, gives a report on their feedback and the value of interdisciplinary investigation in aiding, with the understanding of the meaningmaking process behind collected narratives.

\section{Research interest and background}

This article elaborates on the sixth movement of a postfoundational notion of practical theology and is therefore concerned with giving a description of experiences, which are thickened through interdisciplinary investigation. The experiences of interest are those of the co-researchers who formed part of the larger research study, conducted in 2010, titled 'The spiritual and psychosocial gender specific stories of adolescent orphans affected by HIV and AIDS, in the absence of a father figure: A postfoundational practical theological approach'. The research employed a qualitative research strategy, with the use of the theoretical frameworks of a postfoundational notion of practical theology, narrative therapy and research, and social constructionism. The case study design was chosen as point of departure in collecting and analysing research data with the use of specific collection methods such as focus group interviews, and using a theme-based workbook, collateral observation, participatory observation, interdisciplinary conversations and literature study. ${ }^{1}$ Data were analysed and interpreted with the use of the model of narrative and the seven movements of a postfoundational notion of practical theology as methodology.

Based on the above information, this research investigated the relationship between HIV and AIDS and adolescent male orphans affected by this and all its aspects, such as losing a significant person to death, being impoverished as a result of this loss, being exposed to crime and stigmatisation and being raised without a father role model during the significant developmental years of puberty and adolescence. Furthermore, the research aimed at investigating how these aforementioned events influenced their sexual and power relations with women and their roles as future fathers and husbands.

The aim of this article is, therefore, to provide an illustration of the application of the principles of a postfoundational notion of practical theology, and its sixth movement - an interdisciplinary investigation - as it is applied within this specific research context. In understanding the imperatives behind the sixth movement of a postfoundational notion of practical theology, a short discussion is provided around the key concepts of this epistemological framework. 


\section{Epistemological departure: Postfoundational notion of practical theology}

Van Huyssteen (1999:33) refers to the underlying principle of postfoundationalism as a refigured notion of rationality, which enables a better understanding of various epistemological and hermeneutical concerns, with the use of the epistemic skills of responsible, critical judgement and discernment. He postulates that this notion of rationality assists in the discovery of the value of a variety of resources from different domains of knowledge, in coming to a better interpretation and understanding of a phenomenon or event which is embedded within a specific context and informed by various traditions. What makes this dialogue unique is that no discipline claims expert knowledge; instead the scholars from the various disciplines adopt an attitude of inclusion and non-judgement (cf. Van Huyssteen 1999:33).

This philosophy is based on the conjecture that all knowledge is embedded in a specific local context. This relevant context contains in itself discourses of tradition which assist in the construction and maintenance of the created knowledge. In support of this, Van Huyssteen (2006) states:

Because of our irrevocable contexturality and the embeddedness of all belief and action in networks of social and cultural traditions, beliefs, meaning, and action arise out of our embedded life worlds. (p. 25)

Similarly, Stone (1992:128), in reference to the transactional character of interpreted experience, states that '... experience is always a complex interaction between the self and the world, between the environment and lived feelings'. As a result a postfoundational notion of rationality aims to move beyond objective relations with a particular context, to discard an attitude of relativism, and to include the voices of the traditions that shape the epistemology of such a particular context. This will create a space where scholars from various disciplines can interact as rational beings with the context and the traditions that shape notions of knowledge, which will result in the creation of a form of rationality that creates opportunities for additional interpretations (Demasure \& Müller 2006:418). Van Huyssteen (1999:130) specifically argues for a postfoundational model of rationality which corresponds to an interactionist model of knowledge, creating a vehicle of dialogue that moves beyond objectivism and relativism.

The postfoundational notion of rationality is, therefore, a notion of transaction: a transaction that takes place during an interdisciplinary and cross-contextual conversation where the agents of the conversation presuppose a relational or interactionist view of knowledge (cf. Van Huyssteen 1999:131). This transactional conversation is not aimed at universalism or globalism; it rather suggests that the use of multiple rationalities that reach beyond specific contexts will facilitate an understanding of how this interplay influences cross-contextual beliefs, notions and experiences (Van Huyssteen 1999:177).
Additionally, Van Huyssteen differentiates between context conditioned and context determined which will influence the development of moral and epistemological judgements (Van Huyssteen 1999:147). As a result of conditioning, our cognition and behaviour are products of our relationship with our specific contexts and the traditions contained within these contexts; however, with enough will-power and determination, stepping beyond epistemic boundaries will create opportunities for cross-contextual conversation which will, in turn, allow us to stand in a position of constructive criticism to our traditions (Van Huyssteen 1999:116).

Upon acceptance of the obligation to move beyond our own context into a cross-contextual context, opportunities are created to explore other positive epistemological resources, which enable and enhance the process of interdisciplinary conversation (Van Huyssteen 1999:113). This in turn will create a space of transversality, which is located '... in the domain of our social, communal and institutional practices' (Van Huyssteen 1999:136).

Transversality is a notion of rationality that moves between the two polarities of modernism and postmodernism, so that a safe space can be found where rational communication can take place. Rational communication will invite compliments and critique on praxis, judgements on historical events and assessments, and possible conflicting dialogue, resulting in narrative disclosure (Van Huyssteen 1999:139). It takes us to a place where we can engage in conversation so that we can come to an intelligible, responsible, liberated and just understanding.

Schrag (1992:69ff.) supports this idea and states that during transversal thought, reason operates, functions and manifests itself during the transversal processes of evaluative critique, engaged articulation and incursive disclosure. During evaluative critique, transversality operates either when different practices are merged through processes which show a clear continuity between these practices; or when a collision of different practices takes place which changes or transforms the nature of some of these practices; or when no merger is possible (cf. Schrag 1992:69-70; Van Huyssteen 1999:137). During engaged articulation, discourses are deconstructed so as to provide meaningful and substantial motives for engaging in dialogue with a specific rationality (cf. Van Huyssteen 1999:137). During inclusive disclosure a claim of reality that prevents articulation from encircling itself (cf. Schrag 1992:72) - a realisation is created that relation with the world is only possible through the interpretation of subjective experiences and perception, which results in an appreciation that the world reveals itself through human interpreted experience (Van Huyssteen 1999:138). The characteristics of transversality are revealed during multiand interdisciplinary conversation (Van Huyssteen 2007:19).

The question is, how does this epistemological viewpoint of rationality and interdisciplinary dialogue affect the praxis of practical theology and theological reflection? 
Müller (2005:76-77) states that first and foremost practical theologians should acknowledge that all intellectual efforts are rooted in a specific context and interpreted through subjective epistemological experiences, resulting in a recognition that disciplinary traditions shape the values that inform reflection about God and beliefs about God's presence in the world. Secondly, practical theologians should become increasingly aware of an epistemological movement beyond the boundaries of specific disciplines, contexts, groups and cultures which aims at credible and valid methods for engaging in interdisciplinary dialogue (Müller 2005:76-77). Finally, these scholars should acknowledge that specific traditional resources motivate and enable interdisciplinary dialogue, which is most often expressed through transversal reasoning. This type of transversality promotes diverse and, at times, conflicting viewpoints, creating a dialogical platform for voicing rationalities that can dynamically interact with each other so as to result in meaningful understandings regarding a phenomenon (Müller 2005:76-77).

The emergence of postfoundationalism thus provided practical theology with the opportunity to enhance its reflective practice by ensuring that the evaluation of its epistemes becomes the imperative of practical theology. This is carried out by integrating the model of transversal reasoning into the philosophy and methodology of the discipline of practical theology. The result is a postfoundational notion of practical theology that emphasises the lyrics of locality, embeddedness and situatedness, manifested in the four imperatives of reflection, perspective, experience and presence. Simultaneously these imperatives ensure that practical theology is never too far detached from its theological reflection (Müller 2005:73-74).

Based on a postfoundational notion of practical theology, Müller (2005:78) developed a list of minimum requirements for a corresponding methodology, which enables practical theologians to meaningfully reflect on the experiences of the presence of God. These requirements include: to be locally contextual; socially constructed; directed by tradition; an exploration of interdisciplinary meaning and pointing beyond the local (cf. Müller 2005:78). The remainder of the article provides an example of how the requirement of exploring interdisciplinary meaning, can be applied to the praxis of practical theological research.

\section{Interdisciplinary reflection and interpretation}

Four conversationalists, who acted as the interdisciplinary dialogue team, were approached to engage in dialogue regarding the three ${ }^{2}$ narratives provided. Pseudo ${ }^{3}$ names for three of the co-researchers were used in naming each narrative. Individuals of the interdisciplinary team were

\footnotetext{
2.Group discussions and interviews with co-researchers, Tree of Life camp on two separate instances, 10 to 12 October 2008 , and 26 to 28 February 2010 Magaliesburg Sikelele Camp site.

3.Story 1 was named 'Molimi', story 2, 'Kgotoso' and story 3, 'Manqoba'. The coresearchers have chosen these pseudo names themselves.
}

asked to reflect on each story, using several reflective questions as departure. These questions were:

- When reading the story of Molimi, Manqoba and Kgotoso, what do you think would each of their concerns be?

- How would you formulate your discipline's unique perspective on these concerns and why is it important that this perspective be heard at the interdisciplinary table?

- Why do you think your perspective will be understood and appreciated by researchers from other disciplines?

The three narratives, as given to each team member, follow.

\section{Story 1: Molimi}

Molimi (Sepedi for 'farmer') was born in Modimolle in Limpopo. His parents separated when he was still a baby and his grandparents passed away a few years later. Molimi's mother passed away in 1998 after suffering from a prolonged illness, and his father passed away two years later. Molimi states that the loss of his father did not affect him as much, as his father was never part of his life, and similarly he was too young to understand the death of his mother. At this stage of his life he, however, longs for her presence and, at times, finds it difficult to live without her. The suicide of his cousin in 2003 to whom he was very close, was especially traumatic for him.

Molimi used to share a flat with his older brother and a cousin in the inner city of Pretoria. Molimi was still underage and after having numerous fights with his brother he was taken in by a safe house for orphaned and vulnerable children in Pretoria. He was, however, expelled from this safe house in engaging in inappropriate sexual activities with a fellow house mate and was forced to go back to his brother's flat to live with him. After again being frequently physically attacked by his brother, he ran away from home and lived with some of his friends.

Molimi's brother took over the 'father' role after their parents passed away. He cared for Molimi and often gave him guidance with regard to many issues of life. Nonetheless, his brother frequently abused alcohol and Molimi and his brother's girlfriend would then be the targets of his rage. Therefore, Molimi has ambivalent feelings towards him. Although he is upset with his brother, he also feels guilty as, at the time of this narrative, his brother paid for the rent of the flat in which Molimi lives and at the same time, he is the only 'father' that Molimi knew. As a result he feels that he needs to obey the demands of his brother as he supports him financially, although he feels that in many aspects his brother has failed him. Molimi states, however, that that these events taught him to be strong and independent.

In describing his characteristics, he states that he likes to entertain people and that his friends find him amusing. $\mathrm{He}$ lists his strengths as being a good listener, being quick to make decisions and act on instructions. He says that he is an honest person, and that his friends can talk 'straight' with him. 
Currently (2010) Molimi is enrolled for an Information Technology (IT) course at a college and he earns an extra income by playing music at several night clubs. Molimi says that he is proud of himself in passing grade 12 and being accepted to study at the college and in being able to play music - one of his passions in life.

At the same time, however, he states that he feels disappointed in himself for abusing alcohol and engaging in mischievous behaviour. He says that he might have become used to the 'city life' which promotes this type of behaviour.

Molimi says that in his opinion, a 'real' man is someone who can admit to his mistakes and ask for forgiveness; someone who sets out to make his family happy. He says that he thinks that it is possible to be a good man in today's world, but that there are many temptations. He says that his biggest 'storm' in life is his desire to live a 'Christian life', but not being able to receive the support that he needs in doing so. He says that he is surrounded by people who do not have the same desires and pressure him into doing things that he does not necessarily want to do. Additionally he struggles to overcome the abuse he suffered at the hands of his brother.

With regard to how he views God's presence during his struggles, Molimi states that God has always played an important role in his life, especially in helping him to reconcile with his brother. He believes in 'signs' from God that will point him to the 'right' way. Speaking metaphorically, Molimi says that he wants his 'tree' to be planted next to the valley where there will be enough water to survive. This refers to his wishes in having a family, being happy and able to afford life.

\section{Story 2: Manqoba}

Manqoba (Zulu for 'victory') was born in Mpumalanga and was raised by his grandparents. When he turned 12 , he moved to live with his mother in Pretoria. When he was 15 his mother, however, suddenly fell ill and passed away. He had a bad experience with his extended family who took all his mother's belongings, resulting in him feeling that he has nothing left to remind him of her. He was then accepted by the safe house in Pretoria, because he had nowhere to go. At the time of the camps Manqoba was still very much in grief. He finds it very difficult to come to terms with his mother's death and the actions of his extended family.

Manqoba has one older and one younger sister, and recently became uncle to the child of his oldest sister. He boasts about this fact and states that he feels like a man now. He says that now that his sister is financially independent, she takes good care of him. His sisters, his nephew and his cousins are the most important people in his life.

Manqoba currently (2010) lives in Thembisa with one of his friends and his little sister and two cousins. He wrote grade 12 last year and failed two subjects and, at the time, had to resubmit these subjects before he could apply to study at a college. At the time of both camps, Manqoba seemed a bit indecisive in making a career choice. The possibilities included becoming a pilot, playing soccer, studying graphic design, becoming a music composer and being a disk jockey (DJ). Although he was not sure of his career path, he was adamant that he wanted to be 'successful'.

In referring to the 'storms' that he has experienced, he states that the loss of his mother, and the absence of his father affected him negatively. He says that he experienced his father to be too busy to spend time with him, and tried to compensate for the loss of time by giving him money instead. Manqoba states that he just wanted a father who will teach him how to become a man. Instead, his father abandoned him never to return again.

In referring to his hopes and dreams for the future, Manqoba says that he has set new goals and has renewed plans for the future. He hopes to find happiness in living a life that he always wanted to live. He believes very strongly that God has a 'plan' for him and that he will remain obedient to God. He concludes by saying that his life is tough now, but that he believes in the victory that God has given him to overcome the worst, and that this victory will be the theme of his life.

\section{Story 3: Kgotoso}

Kgotoso (Sesotho for 'peace') was born in Carletonville and is one of two identical twins. Kgotoso experienced a tragedy of events when his father was shot and killed, thereafter his little sister passed away and then his mother was diagnosed with terminal cancer. When his mother passed away, Kgotoso and his brother were still very young and shocked by her death.

In growing up Kgotoso did not see much of his mother as she worked far from home, but he remembers her visiting quite often. He recollects that they would spend time together as a family when she came to visit them, and everyone would make jokes and laugh together. He remembers his mother as a humble and cheerful person and says that he wishes that she was alive to see him become successful. He cannot remember much of his father's family, but he remembers that his mother's family abandoned him and his brother after her death.

Kgotoso is very fond of his twin, and together they compile and produce hip-hop music. He says that he is emotionally very close to his brother and often depends on him for his emotional survival. He sees his brother as the one who guides, comforts, and supports him. He says that, 'My twin he taught me never to run away from my problems'.

Kgotoso says that instead of grieving, he uses the memories of his mother to guide him through life. He states that through shared memories, he and his brother can keep her memory live forever. Kgotoso attributes who he is today to the support he receives from his brother, and the fact that his mother had big dreams for them. He remembers that she wanted more for them in life than what she had, and this idea motivates him to reach for his dreams. 
Kgotoso states that he would like to be successful one day. For him, success is measured in monetary value, visible in the material possessions one has. Additionally he voices the importance of family. Kgotoso says that he found a family in the safe house. Because of this relationship, Kgotoso felt very disappointed when two of his housemates left the house. He states, however, that he takes the wise words that he receives from people to make him strong, for example, the housemother and people from the church who said that he must hold on to God in every situation, and that ...'we become strong from our mistakes'. Kgotoso frequently cites various inspirational comments, perhaps indicating the strength that he receives from them.

The biggest passion in Kgotoso's life is his love for music. He says that he can express himself freely through the music he writes and makes. He concludes that his extended family is now more involved in his and his brother's life. This makes him feel good, although his grandmother passed away the previous year.

\section{Reflections from the interdisciplinary team}

Reflections $^{4}$ that are discussed in this article include reflections from practical theology, pastoral family therapy, critical psychology and social work. These reflections will be given in a summarised and paraphrased format, whilst each story will be discussed simultaneously under each question.

\section{Practical theology}

Dr V. ${ }^{5}$ is the director of a faith-based (FBO) and nongovernmental organisation (NGO) for orphaned and vulnerable children, and a scholar in the field of practical theology. The researcher chose Dr V. as part of the disciplinary team because the broader study situates itself, first and foremost in the field of practical theology.

\section{Concerns of each co-researcher as understood through their narratives}

Dr V. states that Molimi's concerns might include finding a balance between his own personal values and the peer pressure that he constantly experiences. As a result he needs to balance the extent to which he conforms to a lifestyle in contradiction with his own beliefs, whilst at the same time not disappointing himself in terms of what he expects of himself.

Referring to the narrative of Manqoba, Dr V. states that he is clearly concerned about the relationship with his father. She states that issues of forgiveness might become more important to him later in his life. Before approaching this stage, however, she suggests that he might struggle to deal

4.Permission has been obtained from the interdisciplinary conversationalists, prio to the interviews, to publish their reflections. However, pseudo names have been given for each in an atmosphere of professional confidentiality and anonymity.

5.Interviewed on 01 August 2010, Pretoria. with feelings of disappointment and disillusionment. She makes us aware of Manqoba's confession to be holding on to the plan that God has for his life. She predicts that in the future he might have to deal with the challenge of finding out what that really means to him.

Dr V. refers to the concerns of Kgotoso, and says that it seems to revolve around ways to make a success of his life. She states that it is clear that he values his relationship with his brother very much. She predicts that it might be a challenge to sustain that relationship in a changing environment and that he may be struggling to live up to his mother's and his own expectations.

\section{Practical theology's unique perspective on these concerns and importance of voicing it at the interdisciplinary table}

From her discipline's unique perspective, Dr V. postulates that Molimi's awareness of God provides him with a resource for self-motivation and inner discipline that he can built on. He has an awareness to do well, and is trying hard to steer away from doing 'bad' things. God is an important part of his life and he can use this relationship to inspire and motivate him. On the downside, Dr V. states that his God-awareness may lead to unnecessary feelings of guilt and failure. She suggests that these issues might need to be considered during the therapeutic process.

Dr V. states that because of the pivotal theme of forgiveness in Manqoba's narrative, unpacking the role that his mother plays, even after her death, is imperative. The influence of unpacking these stories refers to the unique contribution that practical theology plays in assisting Manqoba to interpret these important life events so that they can contribute to the understanding of his life as a whole. As a result, his view of the future can be strengthened through the imperatives of a faith perspective. According to her, this is what practical theology brings to the table when entering a dialogue with other disciplines.

Referring to the concerns of Kgotoso she states that his faith seems to be a strong motivational factor. This factor can be explored to inspire him to reach his own goals as he will need the inner motivation to live up to all the expectations.

\section{Reasons for a practical theological perspective to be understood and appreciated by researchers from other disciplines}

In responding to the above question Dr V. refers to the concerns of Molimi, and that he voices the important role that religion plays in his life. She says that other disciplines need to understand the contribution that practical theology can make in the role of strengthening Molimi's moral values 
in order to assist him in reaching his own goals in life. With reference to Kgotoso, where he also expresses the value of his faith, she states that it is clear that his dreams for his life are inspired through his faith. In conclusion she states that practical theology can use the value of his faith to help him and others unlock their potential for the future: practical theology can assist people in identifying the strengths of their faith as a resource centre which can be accessed when they need it.

\section{Pastoral therapy}

At the time of this study (2010), Prof. H. $^{6}$ was a professor in pastoral counselling. He was approached in obtaining his insights regarding the related narratives from the field of pastoral therapy.

\section{Concerns of each co-researcher as understood through their narratives}

Prof. H. states his concerns from reading Molimi's narrative around the ambivalence in Molimi's narrative between the feelings of guilt that he experiences with regards to the sexual relations with the girl in the safe house, and the fact that his brother failed him. He states that these ambivalent feelings refer back to the losses of his primary caregivers and that it may be the loss of care from his mother which lead to the intimate relationship with the girl. According to him Molimi substituted his father with his brother. He concludes then that Molimi was too young to integrate these losses into this worldview, being that of a playful boy in which the world was good and he had a place in this good world. He values family life and, as such, this seems to be the symbol of an ideal life for him.

After reading the narrative of Manqoba, Prof. $\mathrm{H}$. lists his concerns as him having issues around passing grade 12 , the loss of his mother, his relationship with his father and the future. He suggests that Manqoba needs to make space for the losses in his worldview and not to easily jump into a view of God which will solve all his issues.

When coming to the narrative of Kgotoso he states that his concerns might be the loss of his sister, his father and mother, his friend and his grandmother. Added to this is the rejection by his extended family and the fact that he sees money as a solution. Prof. H. proposes that Kgotoso needs to accommodate these losses into a solid worldview, which is currently shattered by too many losses which led him to believe that the quick solution to this is making lots of money.

\section{Pastoral therapy's unique perspective on these concerns and importance of voicing it at the interdisciplinary table}

Prof. H. says that he finds it difficult to talk about the discipline of pastoral therapy as a fixed field with clear

6.Interviewed on 31 August 2010 , Pretoria. boundaries. He states that he believes personally in a holistic bio-psycho-socio-spiritual approach to human behaviour. This approach places emphasise on what he calls 'soul care' and states that this refers not only to the spiritual, but also to the whole person. Finding a unique meaning in life is an important aspect of this approach.

In applying this approach to the narrative of Molimi, Prof. $H$. feels that this approach would contribute to the understanding of Molimi's narrative on two levels: a holistic approach tapping into all relevant aspects of his life, not only the bio (or biological), or his drinking problem, but also the psycho (or psychological). In other words, how is he thinking, feeling and perceiving; the socio (or sociological), which includes his context and the impact that it had on his life; and the spiritual, which includes in this case his religion.

Prof. H. refers again to the abovementioned holistic approach in formulating pastoral therapy's unique perspective on Manqoba's issues. He states that pastoral therapy will look at the psychological issues that Manqoba faces, such as how he views various life events. It will also look at the social aspects, such as the coping mechanisms that he employs in dealing with the loss of his mother and abandonment by his father. Finally, this approach will also investigate the spiritual aspects which, in this case, include his view of God and God's plan for his life and soul. He concludes that this approach can assist Manqoba in realising his very essence and creative side so that he can develop his full capabilities and realise his potential.

Referring to the narrative and related concerns of Kgotoso, Prof. H. states that on the biological level Kgotoso's focus on material aspects seems to be - in his view - an easy solution to life's difficulties. On the sociological level he found a new family at the safe house, and finally, on a spiritual level, he feels drawn to wise words and focuses on issues of the soul. From this perspective Prof. H. suggests that one should explore the essence of Kgotoso's self. He states that Kgotoso gives us a glimpse of this essence by stating the importance of music in giving meaning to his life.

Prof. H. therefore concludes that this holistic soul perspective needs to be heard at the interdisciplinary table to prevent a one sided approach in understanding the co-researchers' narratives.

\section{Reasons for the pastoral therapeutic perspective to be understood and appreciated by researchers from other disciplines}

Prof. H. proposes that there is a new awareness amongst disciplines to work holistically. Therefore, according to him, if soul describes the very essence of a person, then this is an important perspective to be heard and appreciated amongst various disciplines. He states that the essence of Molimi, Manqoba and Kgotoso's selves should be determined, in order to focus on long-term healing. Accordingly, this 
approach shows that too much focus on one aspect of a person's functioning can lead to a loss of the real person. Prof. H. concludes that scholars from other disciplines should appreciate this approach because the focus on one's soul is the culmination of all aspects of being a person.

\section{Psychology}

Dr G. ${ }^{7}$ was a lecturer in psychology (2010), and the third interdisciplinary conversant who entered into a dialogue with these narratives.

\section{Concerns of each co-researcher as understood through their narratives}

Dr G. states that all three participants seem to show the expected concerns of adolescents as they try to establish their identities and prepare for adult life. They also share the fact that they have to deal with difficult social circumstances in this important developmental phase. He proposes that they differ in terms of the levels of maturity and 'realism' that they possess. According to him, Molimi seems to be the most differentiated in terms of his dreams and expectations. He states that he has a longer-term future vision in terms of his IT studies; but he also realises that he needs to look after himself in the short term through his involvement in the entertainment industry.

Dr G. says that Manqoba expresses his needs in the same way, but in his opinion, Manqoba is more passive and less focused in satisfying or achieving these needs.

Kgotoso, on the other hand, seems to be quite 'young' in his thinking and does not seem to have any clear direction, according to Dr G. He states that Kgotoso's proclamation that he wants to be a lawyer and a music star, and his motivation that it will provide him with lots of money is undifferentiated and could just be a compensatory strategy to deal with his deep experience of loss and lack in his own life. In the same way, Dr G. says, Kgotoso expresses the need to be able to give others what he does not have. Dr G. concludes that the differences in the impression created by the three participants are also evident in the complexity with which they describe the role of God in their lives.

\section{Psychology's unique perspective on these concerns and importance of voicing it at the interdisciplinary table}

With reference to his discipline's unique perspective, Dr G. responds by saying that he does not believe that psychology as a discipline has a unique perspective. He states, however, that if psychologists are of the opinion that they find themselves in an epoch of blurred disciplinary boundaries, what is important is not the so-called 'unique perspectives' of each discipline, but the mere fact that forums for dialogue are created in order to challenge the blinkers and possible hegemonies associated with strong and rigid disciplinary identities. He says that psychology has many perspectives to offer with regard to the concerns of the participants and that he believes that the perspective offered should have pragmatic and applied value that could contribute to the transformation of the society, community and individual lives.

\section{Reasons for a psychological perspective to be understood and appreciated by researchers from other disciplines}

Dr G. concludes, with reference to the value of the broad psychological perspective, by saying that it is not the 'inherent' or 'essential' strength of the argument or the so called 'truth value' of a perspective that makes it understandable; rather understanding and acceptance is a matter of relationship and goodwill. Therefore, any perspective offered from any discipline would be appreciated if the conditions are created within which meaningful dialogue can happen.

\section{Social work}

The fourth interdisciplinary conversationalist, $\operatorname{Dr} \mathrm{Y}^{8}{ }^{8}$, is a social worker and play therapist in private practice, who focuses on the emotional and social well being of children by utilising a gestalt play therapeutic process to help children deal with the impact of trauma on their lives.

\section{Concerns of each co-researcher as understood through their narratives}

Dr Y. identified Molimi's concerns as having to deal with the theme of loss in his life, with reference to the death of significant people. Molimi makes special mention of missing his mother at this point in his life. According to Dr Y., other concerns include the impact of the anxiety that he experienced when living with his brother (anxiety around the abuse and finances) and his current ambivalence towards his brother (feelings of guilt and resentment). Dr Y. postulates that the fact that his brother does not take responsibility for his behaviour and the consequences thereof, could make it harder for Molimi also to take responsibility for his own life, as this behaviour was not modelled by his brother. Additionally, Dr Y. states, a major concern for Molimi is the trauma he experienced because of the sexual contact he had with a girl from the safe house, and that this incident had a traumatic impact on him and in his own words 'changed my life'. Dr Y. feels that Molimi seems to attribute this incident as the cause of his current drinking problem. A final concern according to Dr Y. is Molimi's struggle to live a good life and have a stable situation, despite the fact that he has a problem with alcohol abuse. Dr Y. notes that despite all of this, Molimi clings to the positive side of his history.

When referring to the narrative of Manqoba, Dr Y. identified several themes of concern. The first theme is also a theme of loss, which includes the death of his mother and the 
abandonment by his father and the fact that Manqoba is still grieving over the death of his mother. The second concern is the unresolved conflict with his mother's family, as they took some of his mother's belongings without his approval. The third and final concern is his academic focus and the fact that he cannot apply for college acceptance. This concern is linked with the fact that he is not sure about his future career.

Finally, she identified several concerns from the narrative of Kgotoso. Firstly, again the theme of loss, e.g. his father getting killed, his sister passing away, and then dealing with the illness and death of his own mother. Dr Y. states that Kgotoso found it particularly difficult to deal with the death of his mother and displays his current unfinished business as wishing that his mother was alive to see him becoming successful. This theme of loss was also accentuated when two of his friends left the house of safety. Secondly, Dr Y. also identified 'conflict with his mother's family' as a theme of concern.

\section{Social work's unique perspective on these concerns and importance of voicing it at the interdisciplinary table}

Dr Y. argues that within the discipline of social work, there are two different important viewpoints to take into consideration, namely generic social work, and a therapeutic point of view. This is the unique contribution that social work brings to the interdisciplinary table.

Referring to Molimi's narrative, Dr Y. has identified four themes of importance to address on both levels of social work intervention. The first theme, and according to Dr Y. the umbrella theme for all Molimi's concerns, is his struggle to have a good life. The remaining three themes are dealing with the theme of loss, dealing with the resulting trauma of the sexual relations incident, and creating positive boundaries and structure in his life.

From a therapeutic social work viewpoint, Dr Y. suggests that an emotionally secure therapeutic process needs to be facilitated where Molimi can gain awareness of his current concerns (called unfinished business in the gestalt therapeutic approach) and various physical and psychological losses; where he is empowered to find appropriate ways (coping mechanisms) of dealing with these concerns and losses; addressing his perceptions about boundaries and sexual relationships; and empower him to attain healthy boundaries in his emotional and social life. She further suggests that he should perhaps consider alternative employment and become involved with other positive social contexts. She suggests some therapeutic tools which can aid this process, for example, memory work, joining a support group, career counselling and life coaching.

Because Molimi is under the age of 18 , he is still under the protection of the Children's Act and a generic social work perspective will focus on facilitating a process where his best interests are protected, based on all aspects of his development and functioning. Therefore Dr Y. suggests that the therapist should appropriately assess the possibility of sexual exposure during his childhood and address some statutory and social justice issues around the specific sexual incident, such as the age of the girl, his and her sexual health, and his relationship with alcohol.

In referring to the narrative of Manqoba, Dr Y. suggests that a therapeutic process could also empower Manqoba to deal with the unfinished business around the losses and conflict he experienced. On a generic level, Dr Y. suggests that because Manqoba is living with his younger sister, a social worker should support this family in ensuring that everyone's best interests are protected, and to provide support for Manqoba's optimal holistic functioning. Guidance can be provided to assist Manqoba in his parenting skill to facilitate a healthy context for his younger sister to grow up in. Referral to a career counsellor is also recommended.

Similar to the cases of Molimi and Manqoba, Dr Y. suggests that the therapeutic process could also empower Kgotoso to deal with the unfinished business regarding the loss of his parents and sister, and the negative memories of his mother's family. She states that from a generic social work perspective, continued services would be aimed at facilitating an emotionally secure context where his best interests are served.

\section{Reasons for a social work perspective to be understood and appreciated by researchers from other disciplines}

Dr Y. states that in order to facilitate a holistic healing and empowering process to all children, it is important that all aspects from the multidisciplinary team be taken into account, especially if there are aspects from the social work context which need to be dealt with. Dr Y. suggests that a contribution from a social work perspective results in a clear, full view of the child's current functioning, and will be for this reason understood and appreciated by researchers from other disciplines.

\section{The researcher's reflection on the interdisciplinary process}

Interdisciplinary investigation will not be complete without a reflection on the interdisciplinary process and shared insights.

In response to the input provided by Dr V., it seems that the value of practical theology as an interdisciplinary conversationalist lies in its power in unpacking spiritual and religious issues inherent in the co-researchers' narratives. Practical theology seems to play a mediating role in assisting a person to acknowledge the role that spirituality or religiosity plays in a person's life and, in doing so, assisting the person to come closer to understanding what moral and ethical role the co-researchers' faith plays in their every-day lives; how their faith influences their 
decisions, their resulting actions and the implications of these on their psychological and sociological well-being. Dr V. emphasised the influence of the co-researchers' faith on the meaning they attribute to their life, past events and future aspirations, and the ability of practical theology to be sensitive to issues such as bereavement, failure, disappointment and forgiveness, and the individual's interpretation of God's role in the actualisation of past, present and future events. It seems that working from a practical theological approach means to not only focus on ostensible religious issues, but to be sensitive to those issues which are interpreted or understood generally from a religious or spiritual perspective, such as forgiveness, acceptance, responsibility and accountability. This approach enhances awareness around the issue of one's view of God and God's providence and how the resulting perceptions influence one's understanding of God's role in the events one had to, and still has to, face.

Prof. H. emphasised a holistic healing perspective and incorporated this into the philosophy of the discipline of pastoral therapy. Instead of limiting this discipline to spiritual and pastoral care, he emphasised a personal view that incorporates the care of the body, the mind, the social and the spiritual into a view of holistic pastoral care, which he refers to as 'soul care'. Prof. H. creates the awareness that traditional pastoral care does not need to limit itself to the study of the spiritual or the religious and its influence on meaning and purpose. He focuses rather on the influence of the biological, the psychological and the social on the spiritual, as the construct of spirituality in turn influences the process of meaning creation. Furthermore, the comments of Prof. H. create the idea that this perspective, as an academic contribution, should be extended through the praxis of pastoral therapy. This indicates, therefore, that interdisciplinary conversation is not only valued during academic dialogue, but is also a valuable tool to improve our professional relations with people in the diverse settings of practical theology.

Dr G. starts the conversation by placing emphasis on the similarities and differences between each of the coresearchers as revealed by their narratives. This is a unique starting point which perhaps indicates that one should first look at the holistic picture in understanding the context and similar environmental influences, retreat from this, and then focus on the unique individual characteristics which include the individual's cognitive and developmental make-up. The consequence is a comprehensive information resource centre which can be shared in meaningful dialogue between each other - an aspect on which Dr G. places much focus. Dr G. provides us with two very important contributions regarding interdisciplinary dialogue, as understood by the broad discipline of critical psychology. Firstly, dialogue between varying disciplines should take place with the aim of having meaningful dialogue. Interdisciplinary dialogue should not take place for the sake of engaging in academic rhetoric alone. Dialogue should focus on challenging the different views and, especially, the biases held by the various disciplines. Ultimately this will result in the second imperative, which indicates that for interdisciplinary dialogue to be meaningful, it should result in pragmatic and applied value, which ultimately results in transformed societies, communities and individuals. Finally, Dr G. emphasises the importance of tending to the psychology of a person in a critical manner, which will include the critical deconstruction of power relationships, of influential macro, meso- and micro contexts and the holistic development of each person, including the use of compensation strategies and the role of spirituality.

Dr Y., working from the perspectives of social work and gestalt principles, highlights the role of certain events in the development of trauma, and the reciprocal role of trauma in hindering healing and aspirations towards the future. She stresses certain themes in the abovementioned narratives that could contribute towards what she calls, 'unfinished businesses'. Through her contributions, Dr Y. underscores the importance of viewing an individual person in two ways. Firstly, to look at the individual in his or her context and identifying issues that threaten the safety of the person and of significant people in the life of the person. Here Dr Y. states that this approach, firstly and foremost, focuses on the protection of best interests, where these interests are based on all aspects of human development and functioning. This she calls the generic viewpoint of social work. Secondly, but not secondary, when all aspects of danger are eliminated, the focus should be on the empowerment of the individual person. This she refers to as the therapeutic viewpoint of social work. Her emphasis on empowerment is quite profound, and differentiates her viewpoints from those of the other conversationalists.

\section{Conclusion}

Insights from the disciplinary team indicate that not only has an interdisciplinary dialogue taken place, but, in fact, also a multidisciplinary and - even - a transdisciplinary dialogue; therefore, a dialogue which acknowledges the complex issues that can only be addressed via dialogue aimed at extending discipline-based concepts and theories and developing novel solutions for praxis that go beyond the boundaries of any specific discipline (cf. Stokols 2006:67). Dialogue like this in this context has one aim in mind; empowering the individual for optimal functioning and integration into society, resulting in attaining ultimate meaning and purpose in life, which in my opinion indicates spiritual actualisation. Of interest during this process is that each team member spoke the same language - the language of transversality - where they entered a 'safe space' to communicate rationally about the issue of concern, with a real concern for the optimal and holistic development of each co-researcher. From the start they entered with a mindset of similar concern, being open to the value that other disciplines can add to the understanding of the phenomenon at hand. 


\section{Acknowledgements}

\section{Competing interests}

The author declares that she has no financial or personal relationships which may have inappropriately influenced her in writing this article.

\section{References}

Demasure, K. \& Müller, J.C., 2006, 'Perspectives in support of the narrative turn in pastoral care', Nederduitse Gereformeerde Teologiese Tydskrif (NGTT) 47(3) 410-419.

Loubser, J. \& Müller, J.C., 2011, 'The use of metaphors in narrative research in exploring and describing experiences of adolescent male orphans affected by HIV and AIDS', HTS Teologiese Studies/Theological Studies 67(2), Art. \#1009, 9 pages. http://dx.doi.org/10.4102/hts.v67i2.1009

Meyer, J., 2013a, 'Adolescent male orphans affected by HIV and AIDS, poverty and fatherlessness: A story of marginalisation?', HTS Teologiese Studies/ Theological Studies 69(1), Art. \#1932, 10 pages. http://dx.doi.org/10.4102/hts.v69i1.1932
Meyer, J., 2013b, 'Deconstructing masculinity: Dominant discourses on gender, sexuality and HIV and AIDS from the experience of the adolescent male orphan',
HTS Teologiese Studies/Theological Studies 69(1), Art. \#1947, 12 pages. http:// dx.doi.org/10.4102/hts.v69i1.1947

Meyer, J., 2014, 'Development of alternative interpretations: The story of an orphaned boy affected by HIV and AIDS and father abandonment', Verbum et Ecclesia 35(2), Art. \#884, 13 pages. http://dx.doi.org/10.4102/ve.v35i2.884

Müller, J.C., 2005, 'A postfoundationalist, HIV-positive practical theology', Practical Theology in South Africa 20(2), 72-88.

Schrag, C.O., 1992, The resources of rationality: A response to the postmodern challenge, Indiana University Press, Bloomington.

Stokols, D., 2006, 'Towards a science of transdisciplinary action research', American Journal of Community Psychology 38, 63-77. PMID: 16791514, http://dx.doi. org/10.1007/s10464-006-9060-5

Stone, J., 1992, The minimalist vision of transcendence: A naturalist philosophy of religion, SUNY Press, Albany, NY.

Van Huyssteen, J.W., 1999, The shaping of rationality: Towards interdisciplinarity in theology and science, Eerdmans Publishing Company, Grand Rapids, MI.

Van Huyssteen, J.W., 2006, Alone in the world? Human uniqueness in science and theology. The Gifford lectures, Eerdmans Publishing Company, Grand Rapids, MI.

Van Huyssteen, J.W., 2007, 'Response to critics', American Journal of Theology and Philosophy 28(3), 409-432. 